\title{
Change of Species and Habitat Diversity in the Pannonian Region of Eastern Lower Austria over 170 Years: Using Herbarium Records as a Witness
}

\author{
Alexandra Grass¹, Karin Tremetsberger¹, Reinhard Hössinger², Karl-Georg Bernhardt1 \\ ${ }^{1}$ Institute of Botany, Department of Integrative Biology and Biodiversity Research, University of Natural \\ Resources and Life Sciences (BOKU), Vienna, Austria \\ ${ }^{2}$ Institute for Transport Studies, Department of Landscape, Spatial and Infrastructure Sciences, University of \\ Natural Resources and Life Sciences (BOKU), Vienna, Austria \\ Email: grass.a@gmx.at, karin.tremetsberger@boku.ac.at, reinhard.hoessinger@boku.ac.at, \\ karl-georg.bernhardt@boku.ac.at
}

Received 8 April 2014; revised 17 May 2014; accepted 5 June 2014

Copyright (C) 2014 by authors and Scientific Research Publishing Inc.

This work is licensed under the Creative Commons Attribution International License (CC BY).

http://creativecommons.org/licenses/by/4.0/

(c) () Open Access

\begin{abstract}
By dint of historical herbarium specimens, we show how changes in species and habitat diversity can be reviewed and correlated with historical events. Our work is based on a digital database of specimens of the BOKU herbarium (WHB), which can be assigned to the Pannonian region of eastern Lower Austria. The complete dataset ( $n=6655$ specimens) was analyzed with the aid of statistical methods allowing computational elimination of collectors' effects (i.e. unbalanced collecting interests of collectors over time; multiple regression analysis, general linear model), from the first herbarium specimens (dating back to 1830) to the present. As a result, a significant decrease in the proportion of species of some habitats (above all water bodies and closely associated habitats, humid and wet meadows, fens and fen meadows, and nutrient poor grassland) was detected. For water-influenced habitats, this decrease correlates with the time of Danube regulation. Moreover, an increase in the proportion of species of ruderal sites was asserted during the observation period. The analysis procedure developed can be used for evaluation of major digitized herbaria in order to trace historical changes in species and habitat diversity.
\end{abstract}

\section{Keywords}

Danube Regulation, Fens, Grassland, Herbarium Analysis, Water Bodies 


\section{Introduction}

With intensification of agriculture and forestry and increased settlement activities, the development of human civilization is heavily transforming landscapes and this transformation is considered to be one of the main drivers of changes in species composition of ecosystems [1]-[5]. Increased rates of species extinctions and species invasions are found at all scales, from local to global [6]. Half of all organisms—plants, animals and microorganisms-living on earth today might have disappeared until the end of the 21st century [7]. Ecosystem properties, however, depend greatly on biodiversity in terms of the functional characteristics of organisms present in the ecosystem [6] [8]-[10]. Through the irretrievable loss of species, the potential for further development of ecosystems gets lost. A high level of biodiversity is essential for the intact ecologic system of the earth. Our agricultural capacity and public health also depend on diverse natural biota and their interspecific relations and activities [7] [11]-[13].

Empirical evidence for tracking historical changes in species and habitat diversity may be based on historical maps, aerial photographs and surveys (e.g. [14]-[20]). However, adequate historical data for studying specific groups of organisms or regions may be very sparse or lacking. Another important source of historical information may stem from museum collections [21]. For example, herbarium specimens in conjunction with other data sources have allowed inferences to be made about drivers of floristic changes [22], probabilities of extinction [23], effects of urbanization on flowering phenology [24], and plant responses to climate change [25]-[28]. Last but not least, historical herbarium records can be a valuable source of information for decision-making in nature conservation efforts. For example, the EU Habitats Directive and national Red Lists need to classify habitats and species of European importance into categories of endangerment. However, use of herbarium records for inference of historical changes may be hampered by misidentifications of specimens, uneven collecting intensity over time and, most seriously, unbalanced collecting interests or foci of collectors over time, the latter two points being especially severe in small herbaria.

Here, we investigate the potential of herbarium records from a single small herbarium for tracking historical changes in species and habitat diversity. Our area of interest is the Pannonian region of eastern Lower Austria, characterized by a warmer and drier climate than the more western parts of Austria. The data source for this analysis is provided by the digitized database of specimens of the herbarium of the University of Natural Resources and Life Sciences, Vienna (WHB), spanning the time period from 1830 to 2007. Specifically, we ask the following questions: 1) Can herbarium specimens be used for inference of changes in species and habitat diversity? If the answer to this question is in the affirmative: 2) How have species and habitat diversity in the Pannonian region changed over the last 170 years? Which specific landscape transformations can be assessed by the aid of the historical specimens? For example, we hypothesize that intensification of agriculture has negatively affected nutrient poor grassland and that settlement activities have led to an increase of ruderal sites. Likewise, we hypothesize that regulation of the Danube river from 1870-1875 has negatively affected habitats influenced by water.

\section{Research Methods}

\subsection{Study Area}

The Pannonian region is mainly situated in the Hungarian lowlands, but it also covers parts of Romania, Serbia, Slovakia, the Czech Republic and Austria, where its westernmost part is localized in Lower Austria and Burgenland. In Lower Austria, the western border of the Pannonian region follows the eastern foothills of the Bohemian Massif (Manhartsberg), from Retz $\left(48.756^{\circ} \mathrm{N}, 15.952^{\circ} \mathrm{E}\right)$ to Krems an der Donau $\left(48.411^{\circ} \mathrm{N}, 15.610^{\circ} \mathrm{E}\right)$, from where it extends to the eastern part of Wachau and the Tullnerfeld. From Vienna southwards, the western border of the Pannonian region follows the eastern foothills of the Northern Limestone Alps (Thermenlinie), to Gloggnitz $\left(47.676^{\circ} \mathrm{N}, 15.938^{\circ} \mathrm{E}\right)$, where it is limited by the eastern foothills of the Central Eastern Alps (Bucklige Welt and Rosaliengebirge) [29] [30]. The Pannonian region is characterized by a warm and dry climate, with an average annual temperature ranging from $8^{\circ} \mathrm{C}-10^{\circ} \mathrm{C}$ (averaged over the years 1901-1950) [31]. Average temperature in July is $18^{\circ} \mathrm{C}$ or higher and the difference between the average temperature in January and the average temperature in July is $20^{\circ} \mathrm{C}-22^{\circ} \mathrm{C}$ [31]. The Pannonian region receives low average annual rainfall, with yearly precipitation ranging from $600-700 \mathrm{~mm}$ (averaged over the years 1901-1950) [32]. In addition to low precipitation, desiccating winds contribute to the dry climate [33]. In Lower Austria, the Pannonian region extends in the 
planar-colline altitudinal zone, with forest steppe, Quercus cerris-Q. petraea forests and Q. petraea-Q. roburCarpinus betulus forests as zonal vegetation and a broad spectrum of thermophile plant communities [30]. The Danube river has shaped the Tullnerfeld and parts of the Vienna Basin (Wiener Becken).

\subsection{Specimens of the BOKU Herbarium}

The data source for this work stems from the herbarium of the University of Natural Resources and Life Sciences, Vienna (WHB). It comprises approximately 59,000 specimens as of June 2013, covering $\approx 9000$ species. The collection focuses mainly on Austria, the former Austro-Hungarian monarchy and the old regional flora of Vienna [34]. The specimens are digitized in an Access database. Query of the database for the keyword "Lower Austria" retrieved 10,419 specimens, which were screened for their belonging to the Pannonian region. 6655 such specimens were retrieved, which represent 1643 species or subspecies.

For further analyses, each specimen was given several attributes describing the affiliation of the species represented by the specimen to a given habitat. Information on the occurrence of species in different habitats was extracted from the habitat descriptions provided for each species in Fischer et al. [35]. Attributes are represented by dummy variables, which take the value of one, if the attribute applies (i.e. the species represented by the specimen occurs in that habitat), and zero otherwise. The primary list of habitats is very diverse (Table 1). In order to achieve a more holistic picture in the analysis, we assembled the primary habitats to aggregate habitats, each of which includes several primary habitats with similar characteristics of vegetation (Table 1).

\subsection{Analysis Procedure}

Prior to the analysis, double and multiple representations of the same species within the same year were removed. The in this way adjusted dataset includes 6,446 specimens. It was evaluated by means of a two step analysis procedure (Figure 1) using PASW Statistics ver. 18.0.0 ( ${ }^{\circ}$ Polar Engineering and Consulting, 19932007).

Table 1. Tested primary habitats and their combination into aggregate habitats.

\begin{tabular}{|c|c|}
\hline Primary habitat & Aggregate habitat \\
\hline Sand; sandy places; sand steppe; sand grassland; gravel & Sand/gravel habitats \\
\hline Loess; loess steppe & Loess habitats \\
\hline $\begin{array}{l}\text { Stony places; stony slopes; edges of stony forests; pine forests; patches of grassland on sunny, rocky } \\
\text { slopes; rocks; rocky slopes; rock steppe; rock grassland; rock crevices; rock vegetation; shady rocks; } \\
\text { lime rocks; lime rock crevices; scree; lime scree; marl scree community of plants }\end{array}$ & Stone/rock habitats \\
\hline Salt steppe; inland salt habitats; salt meadows; humid saline soil; salt lakes; salt vegetation & Salt habitats \\
\hline Quercus pubescens forest; forest steppe & $\begin{array}{l}\text { Quercus pubescens forest/forest } \\
\text { steppe }\end{array}$ \\
\hline Dry grassland; xerothermic grassland; semi-arid grassland; steppe & Dry/semi-arid grassland \\
\hline Nutrient poor grassland; nutrient poor meadows & Nutrient poor grassland \\
\hline Fens; fen meadows; lime-deficient fen meadows & Fens and fen meadows \\
\hline Humid meadows; periodically humid meadows; slightly saline humid meadows; wet meadows & Humid and wet meadows \\
\hline Floodplains; riverside forests; softwood-floodplain vegetation; river meadows; oxbow lakes fallen dry & Floodplains \\
\hline Water bodies; ponds; rivulets; rivers; springs; alder carrs & $\begin{array}{l}\text { Water bodies and } \\
\text { closely associated habitats }\end{array}$ \\
\hline Fields and edges of fields; vineyards; fallow lands; gardens; nutrient-rich soils & Arable weed communities \\
\hline $\begin{array}{l}\text { Ruderal sites; roadsides; motorways; railway facilities; waste disposal sites; quarries; gravel pits; } \\
\text { villages; parks; cemeteries; pavement cracks; artificial turfs }\end{array}$ & Ruderal sites \\
\hline $\begin{array}{l}\text { Pastures; hedges; forests; dry and open forests; forest clearings; edges of forests; dry shrubbery; light } \\
\text { shrubbery; humid shrubbery; edges of shrubberies; edges of xeric shrubbery; dry and open meadows; } \\
\text { flooded meadows; marsh meadows; marshes; source vegetation; ditches; watersides; river banks; } \\
\text { humid banks; reeds; zones of newly formed land; muddy soil; pond bottoms; dwarf rush communities }\end{array}$ & Without assignment \\
\hline
\end{tabular}


In the first step, we tested the attributes assigned to the specimens, i.e. the primary and aggregate habitats according to Table 1, for a linear time trend: Is there a linear increase or decrease in the proportion of species of certain habitats during the observation period from 1830 to 2007? This was done by means of linear regression using the attribute in question as dependent variable (e.g. the affiliation of the species represented by the specimen to the aggregate habitat "water bodies and closely associated habitats"; Figure 2) and the year of collection as independent variable.

A problem of this approach is that some collectors contributed a significant number of specimens to the herbarium. If they had specific interests, the result would be a systematic over- or underrepresentation of certain species or habitats in a given period of time. We solved this problem by creating a dummy variable for each "significant collector" with a minimum of 15 sampled specimens. It takes the value of one if the collector sampled the specimen and zero otherwise. These dummies were included as independent variables in the regression analysis in addition to the year of collection, that way extending the simple linear regression to a multiple linear regression. This procedure computationally eliminates the "collectors bias" from the trend estimation. It can, however, not correct for an eventual "within collectors bias", i.e. for a bias arising from changing interests of a particular collector during his or her collecting career. The independent variables entered in the multiple regres-

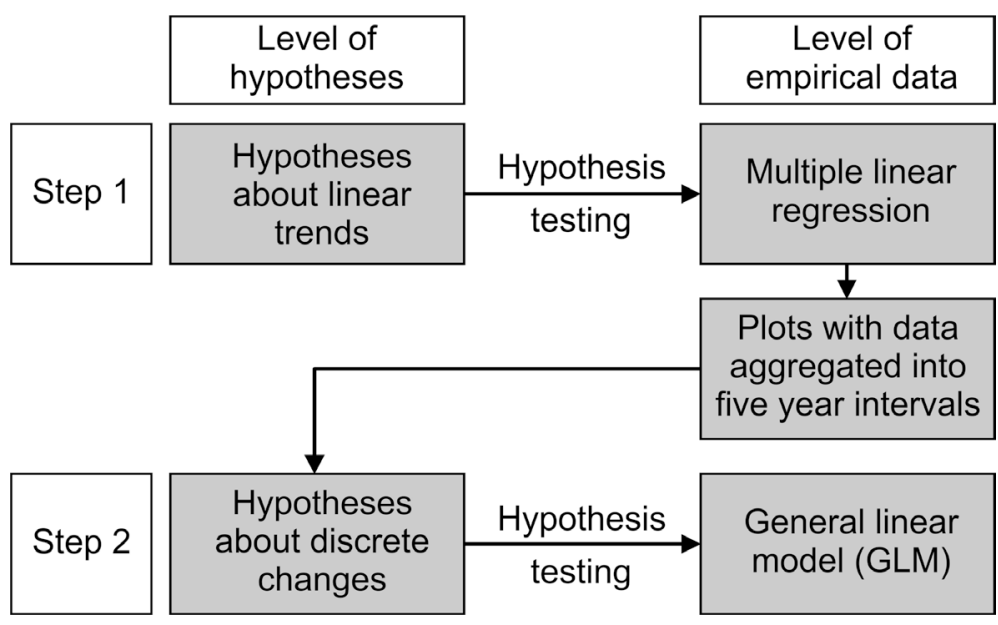

Figure 1. Two step analysis procedure.

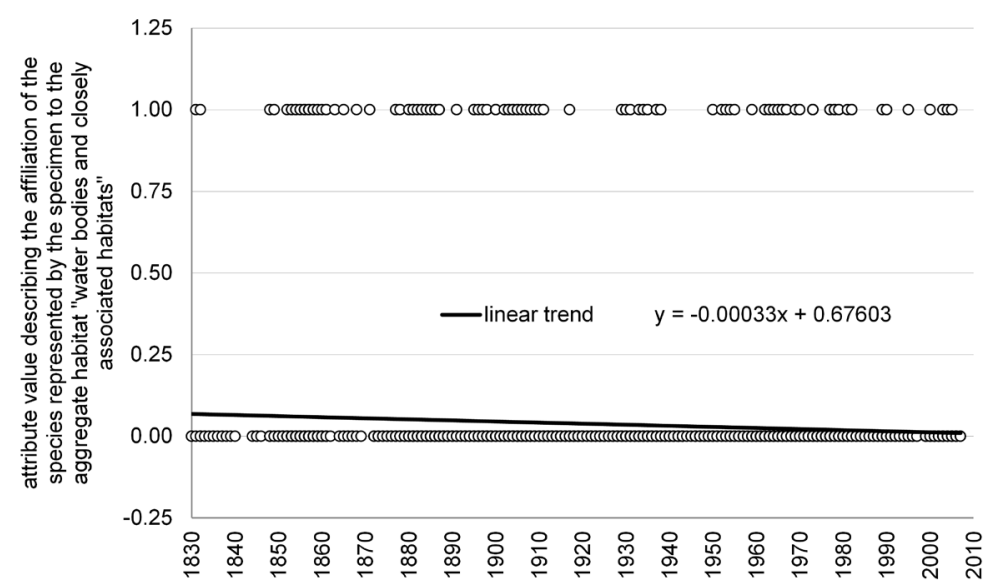

Figure 2. Demonstration of the first step of the analysis procedure of the attribute "water bodies and closely associated habitats" (aggregate habitat): simple linear regression. The $\mathrm{X}$-axis shows the collection year as independent variable. The $\mathrm{Y}$-axis shows the attribute value, i.e. the affiliation of the species represented by the specimen to the aggregate habitat "water bodies and closely associated habitats" according to Fischer et al. [35], as dependent variable. 
sion analysis by the stepwise method. If the year of collection fell out of the model by using the stepwise method, the analysis was repeated by using the enter method of the multiple regression. In the latter case, the entering independent variables were the year of collection and the dummies of those collectors, who had a significant influence when using the stepwise method of the multiple regression analysis. The main result is the estimated parameter of the year of collection, i.e. the regression coefficient describing the effect of year on the proportion of species affiliated to a particular habitat. It describes the average increase or decrease of the dependent variable (e.g. the proportion of species affiliated to the aggregate habitat "water bodies and closely associated habitats"; Figure 3), if the year of collection increases by one unit. The original attribute value is either one or zero. The computational elimination of the collectors' effects causes that the expected values of those specimens, which were sampled by a collector with a specific interest in plants of water bodies and closely associated habitats, are reduced by a factor, which corresponds to the regression coefficient of the dummy variable specifying this collector (Figure 3). The attribute values therefore either fall below one (if the original value was one) or below zero (if the original value was zero). In contrast, it is also possible that the expected value of specimens, which were sampled by a collector, who avoided plants of a particular habitat, are enhanced by a factor corresponding to the regression coefficient of the dummy variable specifying this collector (this case does not apply to the example in Figure 3). In order to distinguish significant trends from barely random fluctuations, the parameter of the year of collection was subjected to a test of statistical significance yielding the error probability $\alpha$ of an erroneous rejection of the null hypothesis $(0 \leq \alpha \leq 1)$.

In the second step, we searched for evidence for a discrete change within the observation period. Plots with data aggregated into five year intervals served for a visual detection of discrete changes. These plots were obtained by plotting the time of collection in intervals of five years on the $\mathrm{X}$-axis and the mean attribute value after elimination of collectors' effects over this five years period on the Y-axis (Figure 4). The linear trend-line in Figure 4 corresponds to the result of the multiple regression analysis (same as in Figure 3). The low number of specimens at the beginning of the observation period (Figure 5) results in a strong fluctuation of the mean attribute values in the early time intervals. For example, the graphic in Figure 4 shows a sudden decline after 1875 that coincides notably with Danube regulation, which took place from 1870 to 1875 . Such a discrete change was tested for by a general linear model using the attribute in question as dependent variable. The main independent variable was a discrete time variable in terms of a dummy. It takes the value of zero, if the specimen has been collected before a given event (e.g. before Danube regulation in 1875), and one otherwise. In order to ac-

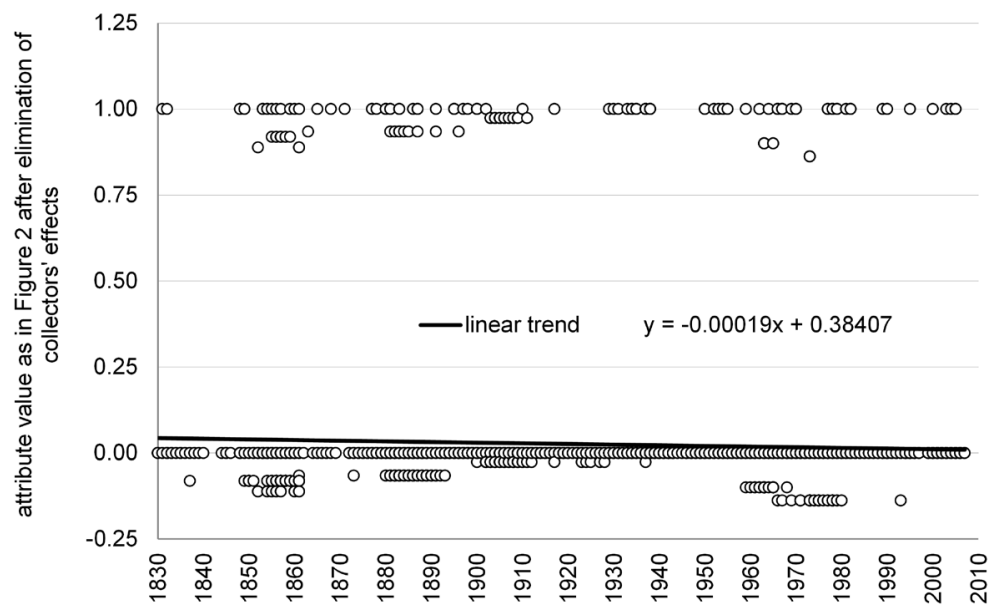

Figure 3. Continuation of the demonstration of the first step of the analysis procedure of the attribute "water bodies and closely associated habitats" (aggregate habitat): computational elimination of collectors' effects by means of multiple linear regression. The $\mathrm{X}$-axis shows the collection year as independent variable. The Y-axis shows the attribute value after computational elimination of collectors' effects as dependent variable. The graphic shows a decreasing time trend $(\alpha<0.05)$, suggesting that the proportion of species belonging to the aggregate habitat "water bodies and closely associated habitats" has significantly decreased in the observation period. 


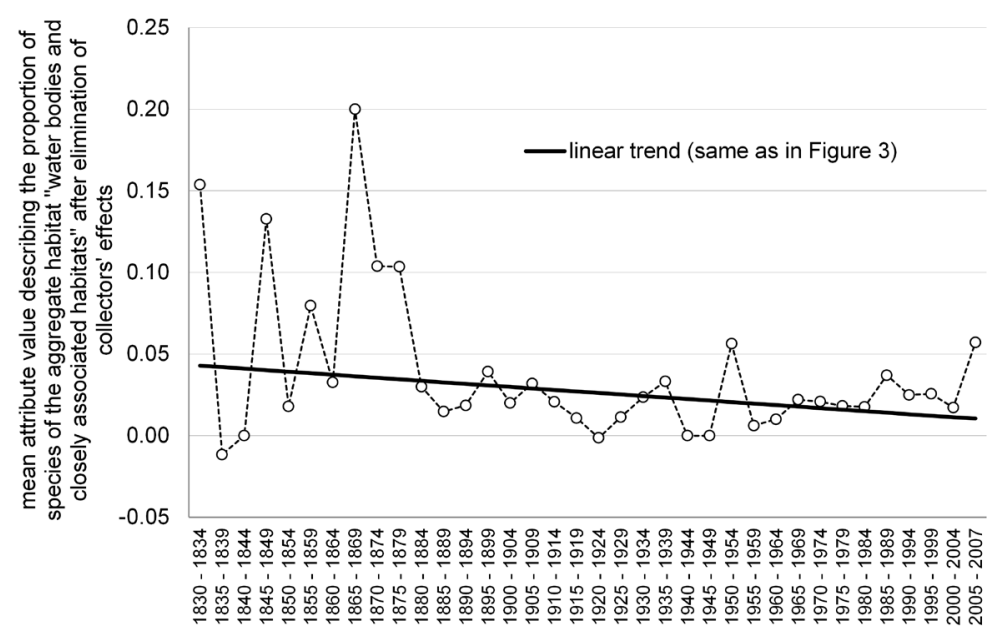

Figure 4. Plot with data from Figure 3 aggregated into five year intervals showing the progress of the mean attribute value after computational elimination of collectors' effects during the observation period. The multiple regression analysis reveals a significant linear decrease over time. The plot, however, shows a sudden decline after 1875 that coincides notably with the Danube regulation from 1870 to 1875 .

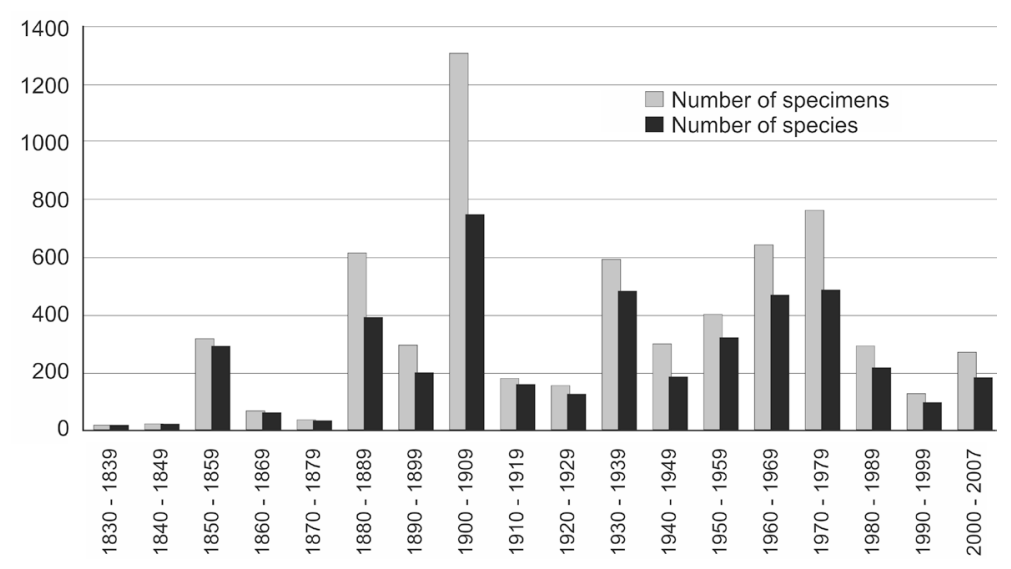

Figure 5. Number of specimens belonging to the Pannonian region of eastern Lower Austria at WHB and number of species represented by these specimens.

count for a possible collectors' bias, the dummies of those collectors with a significant effect in the linear regression were included as additional independent variables. If the effect of a collectors' dummy was no longer significant in the general linear model, it was omitted, so that only significant collectors remained in the model. If the effect of the discrete time variable was not significant $(\alpha>0.05)$, we rejected the hypothesis of a discrete change in the frequency of the attribute.

\section{Results}

Out of all habitats tested (Table 1), four aggregate and four primary habitats show a significant linear time trend in the multiple regression analyses (Table 2).

The aggregate habitat "water bodies and closely associated habitats" comprises all types of water bodies such as ponds, rivulets, rivers, and springs along with their banks, as well as alder carrs. The $\beta$-value of the multiple regression analysis is $-0.00019(\alpha=0.007)$, indicating a $1.9 \%$ reduction in the proportion of species of water bodies and closely associated habitats in 100 years. According to the analysis, the proportion of species of water bodies and closely associated habitats fell from $3.6 \%$ to $0.3 \%$, i.e. to only $7.4 \%$ of the initial value, from the be- 
Table 2. Significant results of the multiple linear regression analyses. Each row corresponds to a separate model. The left column specifies the dependent variable in terms of an attribute, which either applies to the collected species or not. The two other columns show the size and significance of the linear effect of the year of collection on the dependent variable. The effects of the dummy variables of collectors, which served to control for the collectors' bias, are left aside.

\begin{tabular}{|c|c|c|}
\hline \multirow{2}{*}{ Attribute } & \multicolumn{2}{|c|}{ Effect of year of collection } \\
\hline & $\beta$ & P-value $(\alpha)$ \\
\hline Aggregate habitat "water bodies and closely associated habitats" & -0.00019 & 0.007 \\
\hline Aggregate habitat "humid and wet meadows" & -0.00041 & 0.000 \\
\hline Aggregate habitat "fens and fen meadows" & -0.00022 & 0.005 \\
\hline Aggregate habitat “ruderal sites” & 0.00054 & 0.002 \\
\hline Primary habitat "fens" & -0.00018 & 0.016 \\
\hline Primary habitat "fen meadows" & -0.00004 & 0.018 \\
\hline Primary habitat "nutrient poor grassland" & -0.00025 & 0.005 \\
\hline Primary habitat “ruderal sites” & 0.00086 & 0.000 \\
\hline
\end{tabular}

ginning of the recording in 1830 to 2007. The plot with data aggregated into five year intervals (Figure 4) shows a particular decline after 1875 that coincides notably with the Danube regulation from 1870 to 1875 . The general linear model with a threshold of 1875 for the discrete time variable confirms this impression. The parameter is even more significant ( $B=-0.043 ; \alpha=0.000$ ), indicating that a discrete decline at 1875 better reflects the real situation than a linear trend. According to the general linear model, the proportion of species of water bodies and closely associated habitats before and after Danube regulation is $6.1 \%$ and $2.0 \%$, respectively.

The aggregate habitat "humid and wet meadows" comprises permanently or periodically humid to wet meadows, including also slightly saline humid meadows. The proportion of species of this habitat also shows a highly significant linear decrease in the multiple regression analysis $(\beta$-value $=-0.00041 ; \alpha=0.000)$, indicating a $4.1 \%$ reduction in the proportion of species of humid and wet meadows in 100 years. According to the analysis, the proportion of species of humid and wet meadows fell from $11.8 \%$ to $4.5 \%$, i.e. to $38.3 \%$ of the initial value, from 1830 to 2007. The plot with data aggregated into five year intervals (Figure 6) also shows a decline after 1875 , although less pronounced than for species of water bodies and closely associated habitats. The general linear model with a threshold of 1875 for the discrete time variable yields a significant parameter $(\mathrm{B}=-0.152 ; \alpha=$ 0.007), indicating that the proportion of species of humid and wet meadows before and after Danube regulation is $19.0 \%$ and $7.1 \%$, respectively.

Multiple regression analyses of the aggregate habitat "fens and fen meadows" as well as of its two constituent primary habitats, namely "fens" and "fen meadows", also show a significant linear decrease over time. For the aggregate habitat "fens and fen meadows", the $\beta$-value of the multiple regression analysis is $-0.00022(\alpha=$ 0.005), indicating a $2.2 \%$ reduction in the proportion of species of fens and fen meadows in 100 years. According to the analysis, the proportion of species of fens and fen meadows fell from $6.1 \%$ to $2.2 \%$, i.e. to $36.5 \%$ of the initial value, from 1830 to 2007. The plot with data aggregated into five year intervals (Figure 7) does not suggest a sudden step in the decrease. Accordingly, the general linear model with a threshold of 1875 for the discrete time variable reveals no significant difference in the proportion of species of fens and fen meadows before and after Danube regulation.

For the primary habitat "nutrient poor grassland", the $\beta$-value of the multiple regression analysis is -0.00025 $(\alpha=0.005)$, indicating a $2.5 \%$ reduction in the proportion of species of nutrient poor grassland in 100 years. According to the analysis, the proportion of species of nutrient poor grassland fell from $9.9 \%$ to $5.5 \%$, i.e. to $55.3 \%$ of the initial value, from 1830 to 2007. Our a priori-hypothesis was that nutrient poor grassland has been adversely influenced by the use of artificial fertilizers and herbicides in the second half of the 20th century (e.g. [36]). The plot with data aggregated into five year intervals (Figure 8), however, does not suggest a sudden change.

Multiple regression analyses of both the aggregate and primary habitat "ruderal sites" show a significant linear increase over time. For the aggregate habitat "ruderal sites", which comprise roadsides and motorways, 


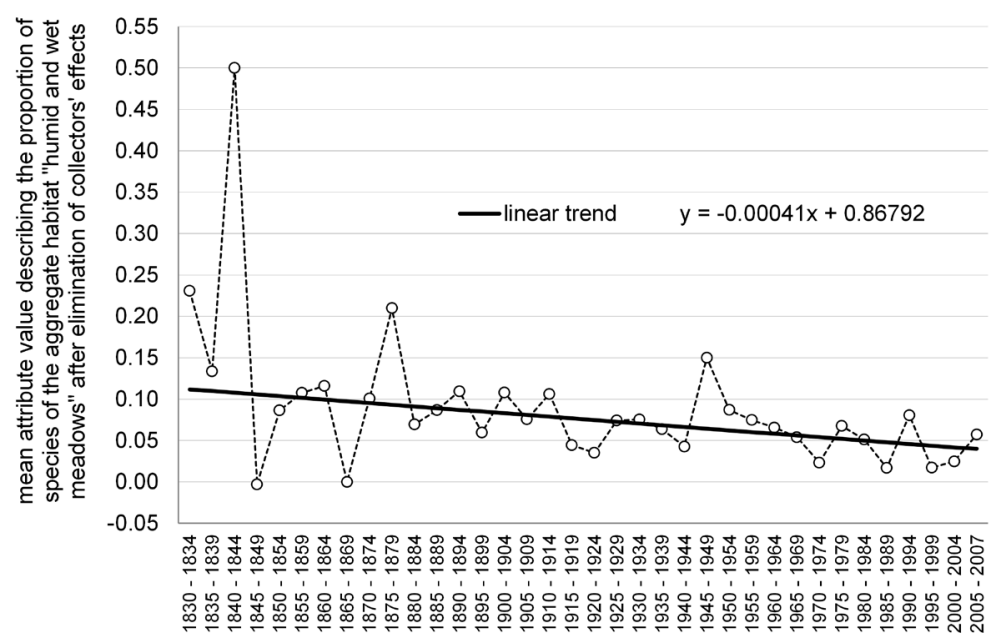

Figure 6. Plot with data aggregated into five year intervals showing the progress of the proportion of species of the aggregate habitat "humid and wet meadows" during the observation period. The multiple regression analysis reveals a significant linear decrease over time. The plot shows a decline after 1875.

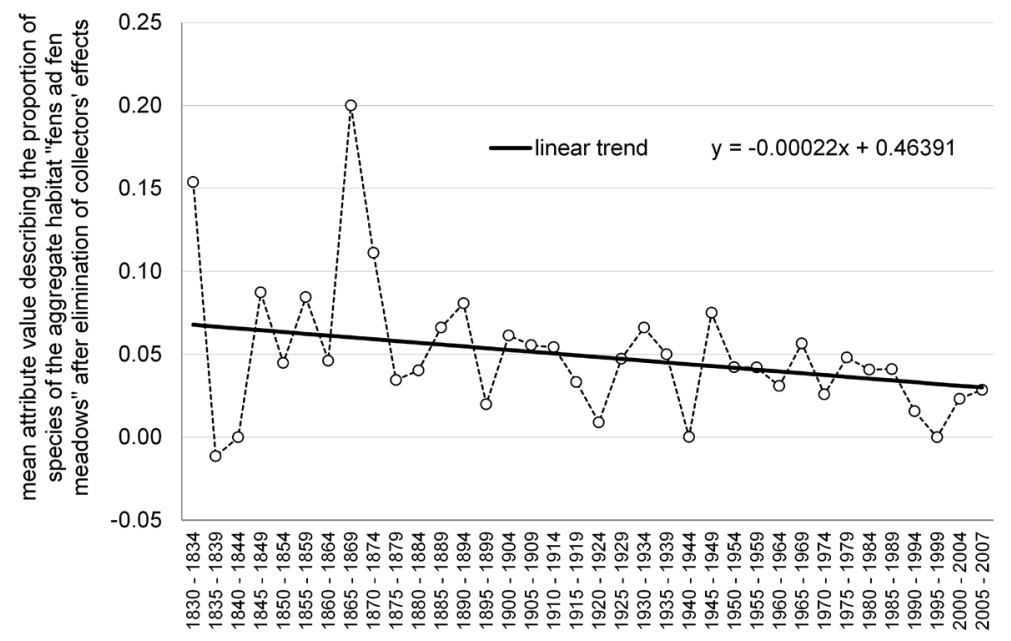

Figure 7. Plot with data aggregated into five year intervals showing the progress of the proportion of species of the aggregate habitat "fens and fen meadows" during the observation period. The multiple regression analysis reveals a significant linear decrease over time.

railway facilities, waste disposal sites, quarries, gravel pits, villages, parks, cemeteries, pavement cracks, as well as artificial turfs besides the primary habitat "ruderal sites", the $\beta$-value of the multiple regression analysis is $0.00054(\alpha=0.002)$, indicating a $5.4 \%$ rise in the proportion of species of ruderal sites in 100 years. According to the analysis, the proportion of species of ruderal sites increased from $17.3 \%$ to $26.9 \%$, i.e. to $155.2 \%$ of the initial value, from 1830 to 2007. Again, the plot with data aggregated into five year intervals (Figure 9) does not suggest a sudden change.

\section{Discussion}

\subsection{Number of Specimens and Number of Species}

Figure 5 shows a strongly fluctuating intensity of the collecting activity during the observation period, possibly reflecting historical events. Before the foundation of the University of Natural Resources and Life Sciences, 


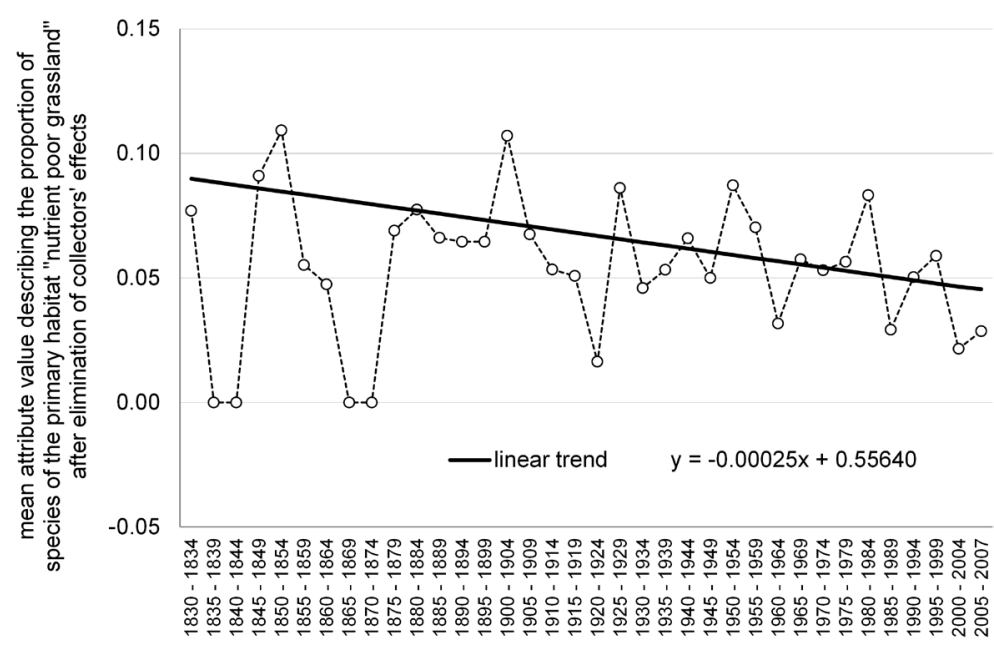

Figure 8. Plot with data aggregated into five year intervals showing the progress of the proportion of species of the primary habitat "nutrient poor grassland" during the observation period. The multiple regression analysis reveals a significant linear decrease over time.

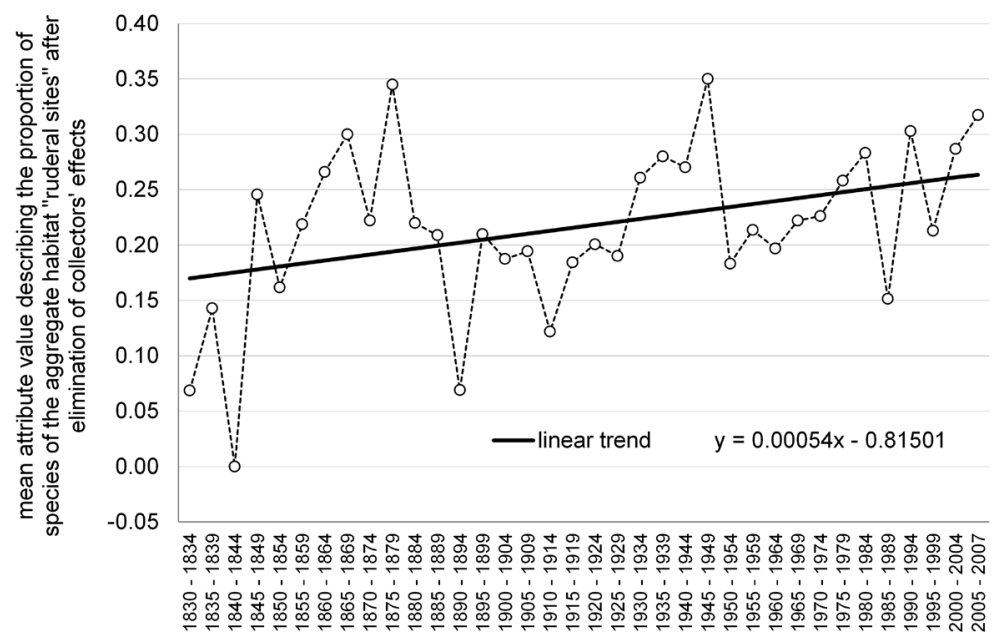

Figure 9. Plot with data aggregated into five year intervals showing the progress of the proportion of species of the aggregate habitat "ruderal sites" during the observation period. The multiple regression analysis reveals a significant linear increase over time.

Vienna, in 1873, Josef Anton Boehm (1831-1893) held a chair of botany [34]. The first herbarium specimens stem from this period. In 1881, the "Flora exsiccata Austro-Hungarica" was initiated by Anton Kerner von Marilaun. Many notable botanists contributed to this project with specimens from the region of the Austro-Hungarian monarchy. This is reflected in a peak in the collecting intensity. At the beginning of the 20th century, Karl Wilhelm and Pius Fürst started a diligent collecting activity, followed by Otto Porsch, Erich Hübl, Walter Forstner, Kurt Zukrigl, and Wolfgang Holzner, among others. Drops in the collecting intensity during the 20th century are marked by World War I and World War II.

\subsection{Interpretation of Herbarium Data}

First, we want to point out that one should always consider that an increasing or decreasing trend in the proportion of species of a certain habitat does not necessarily mean an actual increase or decrease of that habitat. Likewise, a change in the general collecting interest, followed by the majority of the collectors, might result in 
the detection of a trend despite that there is no such trend in reality. Although this possibility is rather unlikely, it should always be kept in mind. Moreover, temporal coincidence of an abrupt change in the proportion of species of a certain habitat with a certain historical event must not necessarily mean a causal connection between the two.

\subsection{Inferred Landscape Transformations over the Last 170 Years}

The analysis showed that the proportion of species of water bodies and closely associated habitats as well as of humid and wet meadows decreased during the observation period and that Danube regulation from 1870 to 1875 can be related to this decrease. It can thus be assumed that the Danube regulation had a direct effect on species, which had their habitat in the dynamic river landscape of the Danube. Moog et al. [37] characterized the Danube in the Tullnerfeld and Vienna Basin as "Lower Alpine Foothills Danube". In this anabranching reach, former braided segments have become disconnected from the main channel. In Austria, the biotope type "large anabranching lowland river" ("Verzweigter Tieflandstrom" [38]) was once exclusively found in the Pannonian region of eastern Lower Austria, but is completely destroyed today due to regulation measures and construction of power plants. The current appearance of the Danube rather belongs to that of a "large straightened lowland river" ("Begradigter Tieflandstrom"). It is still accompanied by extensive riparian forests, which are nowadays protected by the Danube wetlands (Donau-Auen) National Park. The wetland vegetation assemblages along the Danube, however, have considerably changed due to the regulation measures, resulting in absence of floods and lowered ground water levels [39] [40]. Not only regulation of the Danube and other rivers, but also intensification in agricultural land use (e.g. drainage) in the Tullnerfeld and Vienna Basin has contributed to the decline of vegetation associated with water bodies such as alder cars [41].

Humid and wet meadows are formed on riparian forest soil by clearance of the forests. Due to their proximity to running waters they are regularly flooded and provided with nutrients. Humid meadows in the Pannonian region have been continuously and seriously injured by the sinking ground water level and the limitation or entire prevention of seasonal inundations [42]. Moreover, change in agricultural land use has led to cessation of mowing, which resulted in the transformation of the meadows in more species-poor reed zones, and the meadows have been adversely affected by nutrient input [42]. Along the Danube as well as in other parts of Europe, these changes happened mainly after World War II [15] [36] [43] [44]. For example, Bernhardt et al. [45] describe a $69 \%$ loss of historic grassland (i.e. extensive litter meadows on wet soils existing between 1821 and 1946) in the region of Marchegg in eastern Lower Austria. Accordingly, the biotope type "Pannonian and Illyrian wetland meadow" ("Pannonische und Illyrische Auwiese") characteristic of eastern Austria, where its main distribution is along the river March, is categorized as "endangered" in the Pannonian region as well as in the whole of Austria [46].

Our results point in the same direction as previous studies in Europe and North America, which show the general trend of a decline of species and vegetation types associated with water bodies as a response to strong anthropogenic alterations of riverine landscapes. Schütz et al. [47] found that a decline in species richness and a change in community composition of the aquatic vegetation in the Upper Danube riverine system between Donaueschingen and Ulm in Germany occurred after extensive eutrophication commencing in the 1950s and to a lesser extent after channelization carried out mainly in the early 20th century. Danihelka et al. [48] documented the decline of river corridor plants mainly associated with wetlands of large lowland rivers and lowland fen meadows such as Viola elatior, $V$. pumila and $V$. stagnina due to channelization of rivers and subsequent changes in land use, urbanization and recently afforestation in Austria, the Czech Republic and Slovakia. Similarly, Bertin [49] found particularly high species losses among species associated with aquatic habitats, bogs, as well as calcareous terrestrial habitats in the flora of Worcester, Massachusetts, in the 20th century, probably reflecting extensive alteration of many water bodies through siltation, chemical pollution, eutrophication, and stream channelization.

The analysis also showed that the proportion of species of fens and fen meadows decreased during the observation period, but that this decrease cannot be related to the Danube regulation. In the Pannonian region, fens are infrequent and usually associated with calcareous headwaters. Fen meadows are formed on woodland (marsh forests) by deforestation and subsequent use as extensive litter meadows. They were mostly subjected to drainage and change from meadows to profitable farmland and are endangered today [36] [50]. Remnants of fens and fen meadows are found today in small and isolated protected sites in the Vienna Basin such as in the natural monument (Naturdenkmal) Brunnlust. Such habitats are endangered in other European countries as well, as 
exemplified by the history and development of the nature conservation area (Naturschutzgebiet) Reithbruch in Lower Saxony, Germany [51].

The analysis also showed that the proportion of species of nutrient poor grassland, which are most important for the overall biodiversity and therefore have high conservation value [52], decreased during the observation period. The formation of nutrient poor grassland was the result of forest pasture and use of litter with subsequent deforestation or burning of forest trees. Nowadays, the endangerment of nutrient poor grassland is caused by abandonment of pasture farming, easy change into intensive agricultural land, and nutrient input from surrounding agricultural land as well as afforestation and scrub encroachment [46]. For example, Wittig et al. [14] describe a 90\% loss of historic grassland (i.e. grassland existing in 1867) for the Taunus and its Vorland (Hesse, Germany), mainly due to urbanization, conversion into cropland and afforestation. The observed rather continuous decrease in the proportion of species of nutrient poor grassland may suggest that other factors have been responsible for the decrease in addition to the use of artificial fertilizers and herbicides in the second half of the 20th century and/or that their effect came with a time lag. Similarly, Lindborg \& Eriksson [5] found time lags of 50 - 100 years in the response of plant species diversity to changing configuration of habitats in the landscape, when analyzing remnants of traditionally managed semi-natural grassland in Sweden.

The asserted increase of the proportion of species of ruderal sites during the observation period is highly significant. The increase of ruderal sites obviously goes back to increased settlement activities and large space requirement for infrastructure. Similarly, Bertin [28] documented a strong increase in species of disturbed sites in the flora of Worcester, Massachusetts, in the second half of the 20th century. Ruderal sites are strongly influenced by humans, but may nevertheless provide secondary habitats for indigenous species.

\subsection{Usefulness of Herbarium Records for Inferring Landscape Transformations}

This paper asks the question whether statements about changes in species and habitat diversity can be made by analysis of herbarium specimens. In order to evaluate the feasibility of the analytical method, we compare our results with the "Red List of Endangered Biotope Types of Austria" ("Rote Liste der Gefährdeten Biotoptypen Österreichs”) [38] [46] [50] [53] [54]. On the one hand, general trends retrieved by our analysis such as the decline of water bodies and closely associated habitats, humid and wet meadows, fens and fen meadows, and nutrient poor grassland are also recognized in the "Red List of Endangered Biotope Types of Austria". On the other hand, our analysis was not able to recover all biotope types, which are given some category of endangerment in the Pannonian region of Austria in the "Red List of Endangered Biotope Types of Austria". For example, out of 29 forest biotope types occurring in the Pannonian region of Austria, one is "regionally extinct", seven are "critically endangered", two are "critically endangered" or "endangered", and three are "endangered" (regional endangerment in the Pannonian region according to Essl et al. [54]). However, our analysis did not retrieve significant declines for these forest ecosystems. Possible reasons accounting for this include: 1) differing habitat categorizations in the "Red List of Endangered Biotope Types of Austria" compared to the "Field guide of Austria, Liechtenstein and South Tirol” ("Exkursionsflora für Österreich, Liechtenstein und Südtirol”) [35], on which our classifications are based on; and 2) initially low proportions of species of these forest ecosystems and consequently low power of the statistical test. Taken together, however, our results confirm the feasibility of the analytical method. Analysis of herbaria by the proposed analysis procedure could increase our understanding of historical changes in species and habitat diversity in addition to analysis of botanical surveys, phytosociological relevés, historical maps and aerial photographs, which generally do not encompass such long time periods and/or do not enable similarly fine scale habitat categorizations and detection of temporal coincidences with historical changes in land use (e.g. [45] [49] [55]). Analysis of further (larger) herbaria could increase the statistical power for recovering temporal trends in landscape transformations.

\section{Acknowledgements}

The authors are grateful to those collectors who, with their intensive collecting activities, made this work possible. Thanks are equally due to A. Dressler and M. Grass (Vienna) for their support, as well as to an anonymous reviewer for constructive criticism.

\section{References}

[1] Matson, P.A., Parton, W.J., Power, A.G. and Swift, M.J. (1997) Agricultural Intensification and Ecosystem Properties. 
Science, 277, 504-509. http://dx.doi.org/10.1126/science.277.5325.504

[2] Tilman, D., Fargione, J., Wolff, B., D’Antonio, C., Dobson, A., Howarth, R., Schindler, D., Schlesinger, W.H., Simberloff, D. and Swackhamer, D. (2001) Forecasting Agriculturally Driven Global Environmental Change. Science, 292, 281-284. http://dx.doi.org/10.1126/science.1057544

[3] Tilman, D., Cassman, K.G., Matson, P.A., Naylor, R. and Polasky, S. (2002) Agricultural Sustainability and Intensive Production Practices. Nature, 418, 671-677. http://dx.doi.org/10.1038/nature01014

[4] Foster, D., Swanson, F., Aber, J., Burke, I., Brokaw, N., Tilman, D. and Knapp, A. (2003) The Importance of Land-Use Legacies to Ecology and Conservation. BioScience, 53, 77-88. http://dx.doi.org/10.1641/0006-3568(2003)053[0077:TIOLUL]2.0.CO;2

[5] Lindborg, R. and Eriksson, O. (2004) Historical Landscape Connectivity Affects Present Plant Species Diversity. Ecology, 85, 1840-1845. http://dx.doi.org/10.1890/04-0367

[6] Hooper, D.U., Chapin, F.S., Ewel, J.J., Hector, A., Inchausti, P., Lavorel, S., Lawton, J.H., Lodge, D.M., Loreau, M., Naeem, S., Schmid, B., Setälä, H., Symstad, A.J., Vandermeer, J. and Wardle, D.A. (2005) Effects of Biodiversity on Ecosystem Functioning: A Consensus of Current Knowledge. Ecological Monographs, 75, 3-35. http://dx.doi.org/10.1890/04-0922

[7] Pimentel, D., Petrova, T., Riley, M., Jacquet, J., Ng, V., Honigman, J. and Valero, E. (2007) Conservation of Biological Diversity in Agricultural, Forestry and Marine Systems. In: Schwartz, J., Ed., Focus on Biodiversity Research, Nova Science Publishers, New York, 1-25.

[8] Tilman, D., Reich, P.B., Knops, J., Wedin, D., Mielke, T. and Lehman, C. (2001) Diversity and Productivity in a Long-Term Grassland Experiment. Science, 294, 843-845. http://dx.doi.org/10.1126/science.1060391

[9] Loreau, M., Naeem, S. and Inchausti, P. (2002) Biodiversity and Ecosystem Functioning: Synthesis and Perspectives. Oxford University Press, Oxford.

[10] Cardinale, B.J., Srivastava, D.S., Duffy, J.E., Wright, J.P., Downing, A.L., Sankaran, M. and Jouseau, C. (2006) Effects of Biodiversity on the Functioning of Trophic Groups and Ecosystems. Nature, 443, 989-992. http://dx.doi.org/10.1038/nature05202

[11] Perrings, C., Mäler, K.G., Folke, C., Holling, C.S. and Jansson, B.O. (1995) Biodiversity Loss: Economic and Ecological Issues. Cambridge University Press, Cambridge. http://dx.doi.org/10.1017/CBO9781139174329

[12] Pimentel, D., Wilson, C., McCullum, C., Huang, R., Dwen, P., Flack, J., Tran, Q., Saltman, T. and Cliff, B. (1997) Economic and Environmental Benefits of Biodiversity. BioScience, 47, 747-757. http://dx.doi.org/10.2307/1313097

[13] Naeem, S., Bunker, D.E., Hector, A., Loreau, M. and Perrings, C. (2009) Biodiversity, Ecosystem Functioning, and Human Wellbeing: An Ecological and Economic Perspective. Oxford University Press, Oxford. http://dx.doi.org/10.1093/acprof:0so/9780199547951.001.0001

[14] Wittig, R., Becker, U. and Nawrath, S. (2010) Grassland Loss in the Vicinity of a Highly Prospering Metropolitan Area from 1867/68 to 2000 - The Example of the Taunus (Hesse, Germany) and Its Vorland. Landscape and Urban Planning, 95, 175-180. http://dx.doi.org/10.1016/j.landurbplan.2010.01.001

[15] Krause, B., Culmsee, H., Wesche, K., Bergmeier, E. and Leuschner, C. (2011) Habitat Loss of Floodplain Meadows in North Germany since the 1950s. Biodiversity and Conservation, 20, 2347-2364. http://dx.doi.org/10.1007/s10531-011-9988-0

[16] Gillette, D.P., Fortner, A.M., Franssen, N.R., Cartwright, S., Tobler, C.M., Wesner, J.S., Reneau, P.C., Reneau, F.H., Schlupp, I., Marsh-Matthews, E.C., Matthews, W.J., Broughton, R.E. and Lee, C.W. (2012) Patterns of Change over Time in Darter (Teleostei: Percidae) Assemblages of the Arkansas River Basin, Northeastern Oklahoma, USA. Ecography, 35, 855-864. http://dx.doi.org/10.1111/j.1600-0587.2011.06560.x

[17] Aggemyr, E. and Cousins, S.A.O. (2012) Landscape Structure and Land Use History Influence Changes in Island Plant Composition after 100 Years. Journal of Biogeography, 39, 1645-1656. http://dx.doi.org/10.1111/j.1365-2699.2012.02733.x

[18] Bojková, J., Komprdová, K., Soldán, T. and Zahrádková, S. (2012) Species Loss of Stoneflies (Plecoptera) in the Czech Republic during the 20th Century. Freshwater Biology, 57, 2550-2567. http://dx.doi.org/10.1111/fwb.12027

[19] Zu Ermgassen, P.S.E., Spalding, M.D., Blake, B., Coen, L.D., Dumbauld, B., Geiger, S., Grabowski, J.H., Grizzle, R., Luckenbach, M., McGraw, K., Rodney, W., Ruesink, J.L., Powers, S.P. and Brumbaugh, R. (2012) Historical Ecology with Real Numbers: Past and Present Extent and Biomass of an Imperilled Estuarine Habitat. Proceedings of the Royal Society B, 279, 3393-3400. http://dx.doi.org/10.1098/rspb.2012.0313

[20] Coverdale, T.C., Herrmann, N.C., Altieri, A.H. and Bertness, M.D. (2013) Latent Impacts: The Role of Historical Human Activity in Coastal Habitat Loss. Frontiers in Ecology and the Environment, 11, 69-74. http://dx.doi.org/10.1890/120130 
[21] Funk, V.A. (2002) The Importance of Herbaria. Plant Science Bulletin, 49, 94-95.

[22] Gregor, T., Bönsel, D., Starke-Ottich, I. and Zizka, G. (2012) Drivers of Floristic Change in Large Cities-A Case Study of Frankfurt/Main (Germany). Landscape and Urban Planning, 104, 230-237. http://dx.doi.org/10.1016/j.landurbplan.2011.10.015

[23] Chong, K.Y., Lee, S.M.L., Gwee, A.T., Leong, P.K.F., Ahmad, S., Ang, W.F., Lok, A.F.S.L., Yeo, C.K., Corlett, R.T. and Tan, H.T.W. (2012) Herbarium Records Do Not Predict Rediscovery of Presumed Nationally Extinct Species. Biodiversity and Conservation, 21, 2589-2599. http://dx.doi.org/10.1007/s10531-012-0319-x

[24] Neil, K.L., Landrum, L. and Wu, J. (2010) Effects of Urbanization on Flowering Phenology in the Metropolitan Phoenix Region of USA: Findings from Herbarium Records. Journal of Arid Environments, 74, 440-444. http://dx.doi.org/10.1016/j.jaridenv.2009.10.010

[25] Bergamini, A., Ungricht, S. and Hofmann, H. (2009) An Elevational Shift of Cryophilous Bryophytes in the Last Century-An Effect of Climate Warming? Diversity and Distributions, 15, 871-879. http://dx.doi.org/10.1111/j.1472-4642.2009.00595.x

[26] Rumpff, L., Coates, F. and Morgan, J.W. (2010) Biological Indicators of Climate Change: Evidence from Long-Term Flowering Records of Plants along the Victorian Coast, Australia. Australian Journal of Botany, 58, 428-439. http://dx.doi.org/10.1071/BT10053

[27] Panchen, Z.A., Primack, R.B., Aniśko, T. and Lyons, R.E. (2012) Herbarium Specimens, Photographs, and Field Observations Show Philadelphia Area Plants Are Responding to Climate Change. American Journal of Botany, 99, 751756. http://dx.doi.org/10.3732/ajb.1100198

[28] Bertin, R.I. (2013) Changes in the Native Flora of Worcester County, Massachusetts. Journal of the Torrey Botanical Society, 140, 414-452. http://dx.doi.org/10.3159/TORREY-D-13-00039.1

[29] Niklfeld, H. (1964) Zur Xerothermen Vegetation im Osten Niederösterreichs. Verhandlungen der Zoologisch-Botanischen Gesellschaft in Wien, 103-104, 152-181.

[30] Niklfeld, H. (1993) Pflanzengeographische Charakteristik Österreichs. In: Mucina, L., Grabherr, G. and Ellmauer, T., Eds., Die Pflanzengesellschaften Österreichs. Teil I. Anthropogene Vegetation, Gustav Fischer Verlag, Jena/Stuttgart/ New York, 43-75.

[31] Steinhauser, F. and Nowak, H. (1963) Wahre Temperaturmittel Jänner, Juli, Jahr und Jahresschwankung 1901-1950. In: Bobek, H., Ed., Atlas der Republik Österreich, Freytag-Berndt und Artaria, Wien, Blatt III/1 a-d.

[32] Steinhauser, F. and Pippan, T. (1960) Mittlere Jahressummen des Niederschlages 1901-1950. In: Bobek, H., Ed., Atlas der Republik Österreich, Freytag-Berndt und Artaria, Wien, Blatt III/3.

[33] Fink, M.H. (1993) Geographische Gliederung und Landschaften Österreichs. In: Mucina, L., Grabherr, G. and Ellmauer, T., Eds., Die Pflanzengesellschaften Österreichs. Teil I. Anthropogene Vegetation, Gustav Fischer Verlag, Jena/ Stuttgart/New York, 29-42.

[34] Scharfetter, E. and Bernhardt, K.-G. (2002) Das Herbarium des Instituts für Botanik der Universität für Bodenkultur. In: Bundesanstalt für alpenländische Landwirtschaft Gumpenstein, Bericht über das 10. Österreichische Botanikertreffen vom 30. Mai bis 1. Juni 2002, Bundesanstalt für alpenländische Landwirtschaft Gumpenstein, Irdning, 183-184.

[35] Fischer, M.A., Oswald, K. and Adler, W. (2008) Exkursionsflora für Österreich, Liechtenstein und Südtirol. 3. Auflage. Biologiezentrum der Oberösterreichischen Landesmuseen, Linz.

[36] Ringler, A. (1987) Gefährdete Landschaft. Lebensräume auf der Roten Liste. Eine Dokumentation in Bildvergleichen. BLV Verlagsgesellschaft, München.

[37] Moog, O., Sommerhäuser, M., Robert, S., Battisti, T., Birk, S., Hering, D., Ofenböck, T., Schmedtje, U., SchmidtKloiber, A. and Vogel, B. (2008) Typology of Danube River Sections Based on Environmental River Characteristics and Benthic Invertebrate Assemblages. Large Rivers, 18, 127-144. http://dx.doi.org/10.1127/lr/18/2008/127

[38] Essl, F., Egger, G., Poppe, M., Rippel-Katzmaier, I., Staudinger, M., Muhar, S., Unterlercher, M. and Michor, K. (2008) Rote Liste der Gefährdeten Biotoptypen Österreichs. Binnengewässer, Gewässerund Ufervegetation. Technische Biotoptypen und Siedlungsbiotoptypen. Umweltbundesamt, Wien.

[39] Schratt-Ehrendorfer, L. (2011) Donau und Auenlandschaft. Ein Lebensraum voller Gegensätze. In: Berger, R. and Ehrendorfer, F., Eds., Ökosystem Wien, Die Naturgeschichte einer Stadt, Böhlau, Wien, 328-391.

[40] Hohensinner, S., Jungwirth, M., Muhar, S. and Schmutz, S. (2011) Spatio-Temporal Habitat Dynamics in a Changing Danube River Landscape 1812-2006. River Research and Applications, 27, 939-955. http://dx.doi.org/10.1002/rra.1407

[41] Sauberer, N. and Dullinger, S. (2008) Naturräume und Landschaftsgeschichte Österreichs: Grundlagen zum Verständnis der Muster der Biodiversität. In: Sauberer, N., Moser, D. and Grabherr, G., Eds., Biodiversität in Österreich, Räumliche Muster und Indikatoren der Arten- und Lebensraumvielfalt, Bristol-Stiftung, Zürich, Haupt, Bern/Stuttgart/ 
Wien, 16-46.

http://books.google.at/books?id=B4ER7hVWNisC\&printsec=copyright\&hl=de\#v=onepage\&q\&f=false

[42] Sauberer, N. (1993) Zur Bestandessituation der Feuchtwiesen im Pannonischen Raum. Umweltbundesamt, Wien.

[43] Prach, K. (2008) Vegetation Changes in a Wet Meadow Complex during the Past Half-Century. Folia Geobotanica, 43, 119-130. http://dx.doi.org/10.1007/s12224-008-9011-z

[44] Wesche, K., Krause, B., Culmsee, H. and Leuschner, C. (2012) Fifty Years of Change in Central European Grassland Vegetation: Large Losses in Species Richness and Animal-Pollinated Plants. Biological Conservation, 150, 76-85. http://dx.doi.org/10.1016/j.biocon.2012.02.015

[45] Bernhardt, K.-G., Lapin, K. and Werschonig, E. (2010) The Future of Plant Diversity in Grassland Farming Vegetation-A Review of Diversity in a Strongly Transformed Agricultural Landscape. Biotechnology in Animal Husbandry, 26, 205-217.

[46] Essl, F., Egger, G., Karrer, G., Theiss, M. and Aigner, S. (2004) Rote Liste der Gefährdeten Biotoptypen Österreichs. Grünland, Grünlandbrachen und Trockenrasen. Hochstaudenund Hochgrasfluren, Schlagfluren und Waldsäume. Gehölze des Offenlandes und Gebüsche. Umweltbundesamt, Wien.

[47] Schütz, W., Veit, U. and Kohler, A. (2008) The Aquatic Vegetation of the Upper Danube River-Past and Present. Large Rivers, 18, 167-191. http://dx.doi.org/10.1127//r/18/2008/167

[48] Danihelka, J., Niklfeld, H. and Šípošová, H. (2009) Viola elatior, V. pumila and V. stagnina in Austria, Czechia and Slovakia: A Story of Decline. Preslia, 8, 151-171.

[49] Bertin, R.I. (2002) Losses of Native Plant Species from Worcester, Massachusetts. Rhodora, 104, 325-349.

[50] Traxler, A., Minarz, E., Englisch, T., Fink, B., Zechmeister, H. and Essl, F. (2005) Rote Liste der Gefährdeten Biotoptypen Österreichs. Moore, Sümpfe und Quellfluren. Hochgebirgsrasen, Polsterfluren, Rasenfragmente und Schneeböden. Äcker, Ackerraine, Weingärten und Ruderalfluren. Zwergstrauchheiden. Geomorphologisch Geprägte Biotoptypen. Umweltbundesamt, Wien.

[51] Müller, J. and Kuhbier, H. (2006) Geschichte, Entwicklung und Vegetationsveränderungen der Kalkflachmoorwiese im NSG Reithbruch (Lkr. Osterholz) bei Bremen. Abhandlungen des Naturwissenschaftlichen Vereins zu Bremen, 46, $101-124$

[52] Ellmauer, T. (1996) Die Bedeutung von Wiesengesellschaften für Biodiversität und Naturschutz in Österreich. Verhandlungen der Zoologisch-Botanischen Gesellschaft in Österreich, 133, 277-299.

[53] Essl, F., Egger, G. and Ellmauer, T. (2002) Rote Liste Gefährdeter Biotoptypen Österreichs. Konzept. Umweltbundesamt, Wien.

[54] Essl, F., Egger, G., Ellmauer, T. and Aigner, S. (2002) Rote Liste Gefährdeter Biotoptypen Österreichs. Wälder, Forste, Vorwälder. Umweltbundesamt, Wien.

[55] Wang, J., Eyre, T.J., Neldner, V.J. and Bean, T. (2011) Floristic Composition and Diversity Changes over 60 Years in Eastern Mulga Communities of South Central Queensland, Australia. Biodiversity and Conservation, 20, 2759-2778. http://dx.doi.org/10.1007/s10531-011-0104-2 
Scientific Research Publishing (SCIRP) is one of the largest Open Access journal publishers. It is currently publishing more than 200 open access, online, peer-reviewed journals covering a wide range of academic disciplines. SCIRP serves the worldwide academic communities and contributes to the progress and application of science with its publication.

Other selected journals from SCIRP are listed as below. Submit your manuscript to us via either submit@scirp.org or Online Submission Portal.
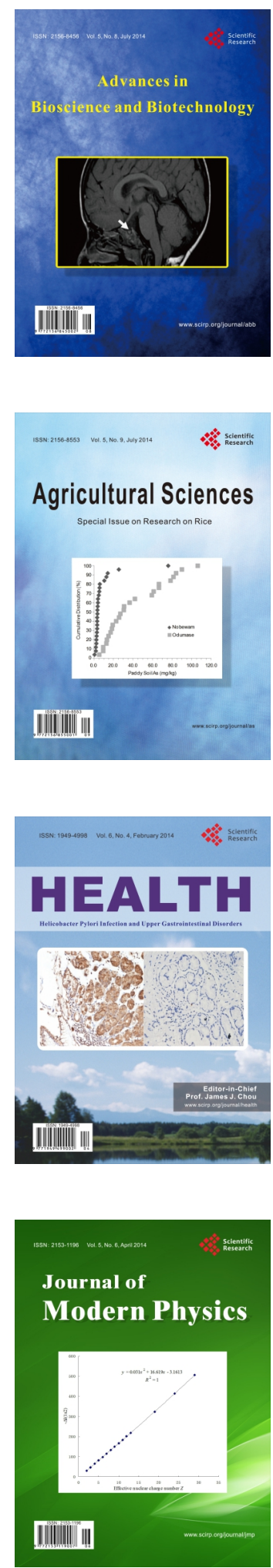
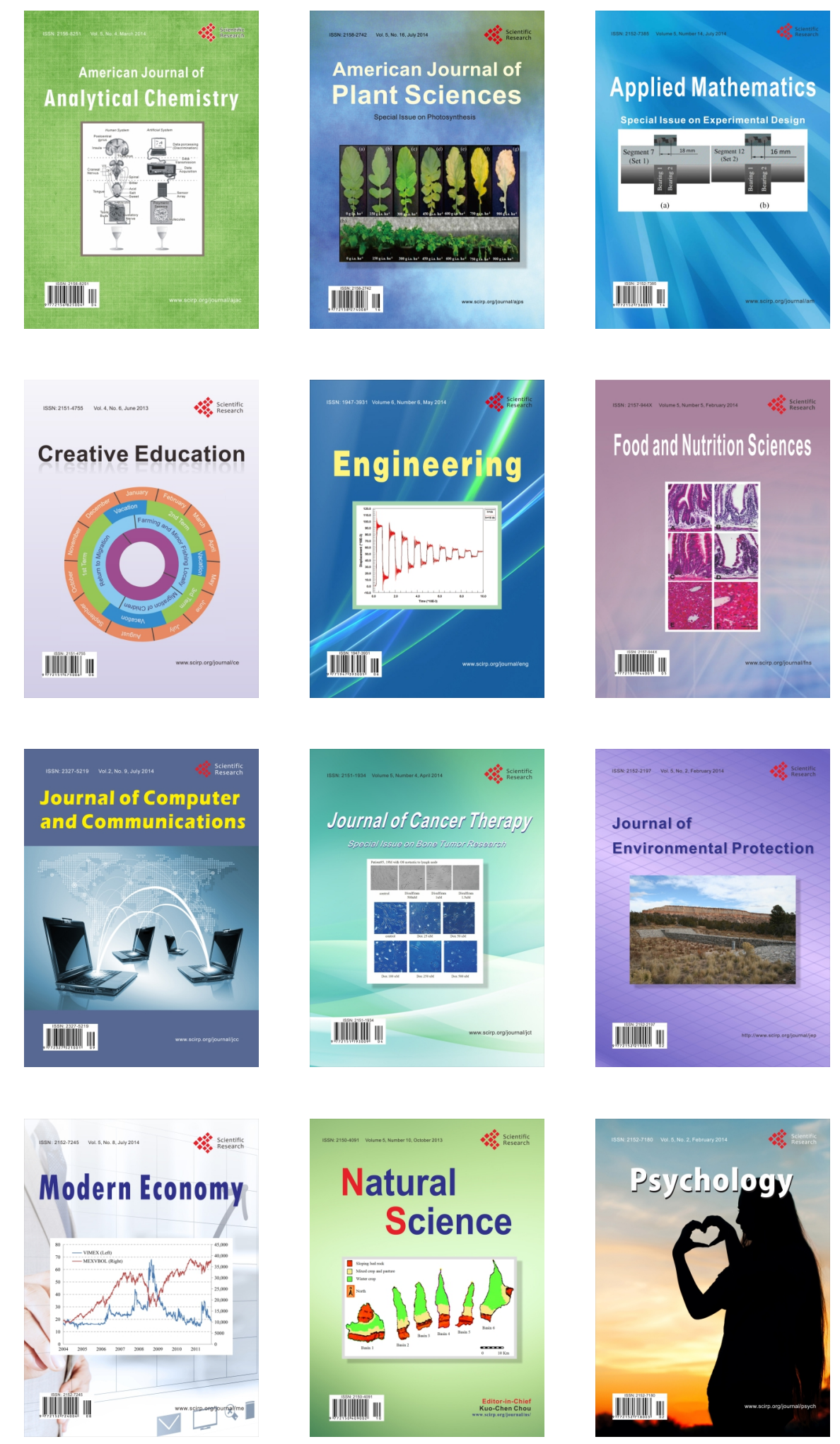